\title{
The Influence of Gender Roles and Coping Strategies to The Fishermen's Family Happiness Index
}

\author{
Rona Aulia Karimah ${ }^{1}$, Herien Puspitawati ${ }^{2 *}$ \\ ${ }^{1,2}$ Department of Family and Consumer Sciences, Faculty of Human Ecology, IPB University, \\ Bogor 16680, West Java, Indonesia \\ *) Correspondent author: herien_puspitawati@gmail.com
}

\begin{abstract}
Seasonal changes will have an impact on the lives of fishermen's families, especially the economic sector. Changes in the sea and non-sea seasons have an impact on family cooperation in survival. These effects will be seen in the gender role of husband and wife in solving problems in fishermen's families. This study aims to analyze the effect of gender roles and coping strategies on fishermen's family happiness index. The study design used a crosssectional study with interviews and questionnaire assistance. The research sample was selected by purposive sampling with respondents of 40 fishermen's families in the Toboali District, Bangka Belitung Islands Province. The gender role variables, coping strategies, and fishermen's family happiness index are in the medium category. There is a correlation between coping strategies with the happiness index of fishermen's families. The number of family members shows a significant negative effect on the happiness index in the sea and non-sea seasons. Meanwhile, coping strategies present a significant positive effect on the happiness index of fishermen's families in the sea and non-sea seasons.
\end{abstract}

Keywords: coping strategies, gender roles, family happiness index

\begin{abstract}
Abstrak
Perubahan musim akan berdampak bagi kehidupan keluarga nelayan khususnya sektor perekonomian. Perubahan musim melaut dan tidak melaut memberikan dampak terhadap kerja sama keluarga untuk bertahan hidup. Hal tersebut mempengaruhi peran gender yang dilakukan suami istri untuk menyelesaikan masalah di dalam keluarga nelayan. Penelitian ini bertujuan menganalisis pengaruh peran gender dan strategi koping terhadap indeks kebahagiaan keluarga nelayan. Desain penelitian menggunakan studi cross-sectional dengan wawancara dan bantuan kuesioner. Sampel penelitian dipilih secara purposive sampling dengan responden sebanyak 40 keluarga nelayan di Kecamatan Toboali, Provinsi Kepulauan Bangka Belitung. Variabel peran gender, strategi koping, dan indeks kebahagiaan keluaraga nelayan berada pada kategori sedang. Terdapat hubungan antara strategi koping dengan indeks kebahagiaan keluarga nelayan. Jumlah anggota keluarga berpengaruh negatif signifikan terhadap indeks kebahagiaan pada musim melaut dan musim tidak melaut. Strategi koping berpengaruh positif signifikan terhadap indeks kebahagiaan keluarga nelayan pada musim melaut dan musim tidak melaut.
\end{abstract}

Kata kunci: indeks kebahagiaan keluarga, peran gender, strategi koping 


\section{Introduction}

Fishing is mainly influenced by sea conditions and fish season changes due to wind movements. Wind movements in Indonesia to divided into two, namely the east monsoon that occurs in May to July and the west storm that occurs in October to April (Saefudin, 2003). The condition of the east wind with the waves is not stable, and many fish that easily caught in small seas are often called the sea season. The west season is commonly referred to as the no-sea season because, in that season, the storm and waves are high, so fishermen cannot go to sea (Irwan, Nugroho, \& Zulkarnain, 2017). Most of the characteristics of coastal communities depend on factors that influence the uncertainty of fishing life, such as the season, fish prices, and markets (Wahyono, Imron, \& Nadzir, 2014). For the fishing community, there are two seasons, the west season and the east season. The west season is often referred to as the no-sea season because in that season, the storm and waves are high, so fishermen cannot go to sea. While in the east season or at sea season, also called season of small sea waves and so many fish to catch.

The season of going to sea and not going to the sea significantly affect the role of gender in the fishermen's family. When fishing season, the fishermen always at sea to fish and not at home every day. This has an impact on fisherman's wives. Domestic fishermen's matters are more burdened to the fishermen's wife. However, in the season not going to sea, the husband did not fish in the sea and chose to at home. The wife of a fisherman decides to work outside the house to supplement the family income. According to Kusumo, Charina, and Mukti (2013), reveal that the party most burdened and responsible for overcoming and maintaining the survival of

households in facing the economic vulnerability of the fishermen's family poverty are the fishermen's wife.

Seasonal changes have an impact on the economic sector of fishing families. Fisherman families will experience a crisis of fulfilling their needs if income is vulnerable. This causes pressure and stress on every family member to meet their family needs. The efforts made by the family in overcoming the problems and stress they face are called coping strategies. Coping strategies are behaviors that accept, tolerate, minimize stressors with the ability to think and behave in stressful situations (Lazarus, \& Folkman, 1984). If the welfare of the fishermen's family can be achieved through coping strategies, it will bring happiness to the fishermen's family. Through a good coping strategy, it expected that family goals could easily achieved so that the index of happiness and satisfaction levels will increase.

Suandi (2007), states that welfare with a subjective approach is measure from the index of happiness and satisfaction felt the people themselves, not others. According to Easterlin (1974), measuring happiness should not only consider welfare goals such as health and socio-economic status but subjective welfare measures such as satisfaction and quality of life. The division of gender roles is inseparable from coping strategies in living family life. The division of gender roles and coping strategies that can be implemented well can form a balanced and harmonious family so that family welfare in a sustainable manner can be achieved with an index of happiness.

Family life wants family satisfaction and happiness both in one's own family and the surrounding environment. If the fulfillment is disrupted, then there are efforts to restore the condition by dividing gender roles and coping strategies that are suitable for the family. The division of gender roles and coping strategies that are implemented 
well; this can form a balanced and harmonious family so that family welfare in a sustainable manner can be achieved with an index of happiness.

Based on the phenomena that exist, the study examines the related effects of gender roles and coping strategies on the fishermen's family happiness index. Many previous studies explain the impact on the subjective well-being of the family, but it did not reveal more specifically related to the happiness index. Based on the explanation of the problem above, the objectives of this study are to 1) analyze differences in family characteristics, gender roles, coping strategies, and the happiness index of fishermen families in fishing and non-fishing seasons; 2) analyze the correlation of family characteristics, gender roles, coping strategies, and happiness index of fishermen families in the sea and non-sea seasons; 3) analyze the influence of family characteristics, gender roles, coping strategy on the happiness of fishermen families in the sea and non-sea seasons.

\section{Methods}

\section{Participants}

This study uses a cross-sectional study design. The study was conducted in the Bangka Belitung Islands Province, which is one of the provinces that have a significant potential of fisheries resources in Indonesia but is still traditional. The location of this study at the village of Tanjung Ketapang and data carried out in April 2019. The number of samples was 40 people who lived and settled in the same area. The sampling technique of this study is non-probability sampling with purposive sampling. Sampling in this study was conducted by non-probability sampling with a purposive sampling technique. The study population is a traditional fishing family in the village of Tanjung Ketapang. Research respondents are traditional fishermen's wives from families with at least one child. Characteristics of a traditional fisherman wife, coming from a complete family (having a husband), and having at least one child. That is due to considerations for looking at items in the domestic gender role.

\section{Measures}

The study was divide into three research variables, namely gender roles, coping strategies, and happiness index. Gender roles were measured using a questionnaire modified by researchers from Krzaklewska (2014) and Puspitawati (2013). Krzaklewska's Journal (2014) titled Measurement of Gender Equality - Alaysing Dimensions, Embracing Areas, Considering Contexts. Gender roles are divide into three domains, namely domestic, public, and social. Measurement of gender roles is done by referring to instruments in the Journal having 24 statement items, consisting of 15 statements for the domestic domain, five statements for the public domain, and four statements for the social domain. The instrument in this study was modified each statement characteristics from a sample, such as other significant sources that have been interpreted as gender roles of the fishing families. The instruments were measured using the following categories, i.e. $1=$ husband only; $2=$ dominant husband; 3 = equal husband and wife; $4=$ dominant wife; $5=$ wife only; $6=$ others with Cronbach's alpha value of 0.858 . When processing gender role variable data, a score data is recoded to see gender cooperation taking place, such as $1=$ husband $/$ wife only; $2=$ dominant husband / wife; $3=$ equal husband and wife; and $0=$ others. The 'other' result was given a score of 0 because this study only focused on gender cooperation between 
husband and wife. The minimum value that can be obtained from the gender role instrument is 0 , and the highest value is 72 .

The main concept of coping strategies used in this study is the concept of Lazarus and Folkman (1986). The concepts of Lazarus and Folkman distinguish coping strategies into two dimensions; namely, coping strategies focus on problems, and coping strategies focus on emotions. Coping strategy variables are measure from instruments modified from Lazarus RS and Folkman RS (1986). The instrument of Lazarus and Folkman (1986) has 66 questions, then modified and reduced to 20 statements according to consideration of sample characteristics. The dimension of focus on the problem consists of 6 statement items, and the dimension of focus on emotions consists of 14 statement items. The modified instrument was measured using a Likert scale (14), i.e. $1=$ never; $2=$ rare; $3=$ often; $4=$ always with Cronbach's alpha value of 0.836 .

Happiness index theory that refers to Hills and Argyle (2002) happiness journal, through a memoir entitled The Oxford Happiness Questionnaire: a Compact Scale for The Measurement of Psychological Well-being. Happiness index variables are measure from a modified questionnaire from SPTK BPS (2017) and the Oxford Happiness Questionnaire (OHQ) (Hills \& Argyle, 2002). The original SPTK questionnaire consists of 40 statements, and OHQ consists of 29 statements, then it was modified to 10 SPTK statements and five OHQ statements to measure the happiness index of fishermen families. The instrument was measured using a Likert scale (ordinal), with the initial value range 1-6 changed to 1-4. This change is based on consideration of the characteristics of respondents to make it easier to determine the assessment. Interpretation of grading 1-4, i.e., 1 'strongly disagree,' 2 'disagree,' 3 'agree,' and 4 'strongly agree' with Cronbach's alpha value of 0.836 .

\section{Analysis}

The data obtained is then processed through the process of data entry, data cleaning, editing, coding, scoring to the data analysis stage. The type of data analysis carried out in the form of descriptive analysis and inference analysis. The statistical analysis method in the form of descriptive analysis to used find out the description of the variables studied. The variables studied included family characteristics, gender roles, coping strategies, and family happiness index to find out the average, standard deviation, minimum, and maximum data distribution. Descriptive analysis for gender role variables, coping strategies, and family happiness index using a cut off by Sunarti et al. (2005), Khomsan (2009), and Abdullahi et al. (2016) that is, low $(<60)$, moderate (60-79), and high ( $\geq 80)$.

The statistical analysis method in the form of inference analysis to used determine the relationship and influence between the variables studied. The Pearson correlation test was conducted to test the correlation between the two research variables. These variables are the characteristics of family-gender roles, characteristics of family-coping strategies, gender-coping strategies, family characteristics-index of happiness, genderindex of happiness roles, and happiness-coping strategies. The analysis is used to determine the strengths and weaknesses of the correlations between variables. The influence test uses a multiple linear regression test that involves variables, such as family characteristics, gender roles, coping strategies, and happiness index. 


\section{Findings}

\section{General Description of the Study Area Conditions}

The research location was in Tanjung Ketapang Village, Toboali District, South Bangka, Bangka Belitung Islands Province. Families residing in the village of Tanjung Ketapang have the most sources of livelihood as fishing fishers. Fishermen in the village of Tanjung Katapang have a developing economic life and have not utilized advanced technology to catch fish, so they are referred to as traditional fishermen. Traditional fishermen are fishermen who use simple fishing technology-generally fishing equipment manually or with human labor. Fishermen catch fish at sea in the sea season. However, fishermen will look for other side jobs to supplement the family income during the non-fishing season. That is because the fish catch results are small; thus, fishermen wives work as housewives, and others work as employees or traders. In the non-fishing season, the fisherman's wife works to supplement the family income. The wife of a fisherman processes fish products to be made into shrimp paste and kemplang crackers. Processed products are sold to neighbors or souvenir shops.

\section{Family Characteristic}

Age. The age group of husband and wife is classified into three categories, namely early adulthood, middle adulthood, and advanced adulthood (Hurlock, 1980). The results show that the husband and wife of the fisherman family are in the early adulthood category. The wife's age is higher in the early adult category $(57.5 \%)$ compared to other age categories. Meanwhile, the husband's age is more upper in the early adult category $(52.5 \%)$ compared to different age categories.

Table 1 The distribution based on the social characteristics of the respondent's family

\begin{tabular}{|c|c|c|c|c|c|c|}
\hline \multirow{2}{*}{ Category } & \multicolumn{3}{|c|}{ Husband } & \multicolumn{3}{|c|}{ Wife } \\
\hline & $\mathrm{N}$ & $\%$ & mean \pm std & $\mathrm{n}$ & $\%$ & mean \pm std \\
\hline \multicolumn{7}{|l|}{ Age (year) } \\
\hline Early adulthood (18-40) & 21 & 52,5 & \multirow{3}{*}{$\begin{array}{c}41,85 \pm \\
10,61\end{array}$} & 23 & 57,5 & \multirow{3}{*}{$\begin{array}{c}38,82 \pm \\
9,57\end{array}$} \\
\hline Middle adulthood (41-60) & 18 & 45,0 & & 17 & 42,5 & \\
\hline Advanced adulthood $(>60)$ & 1 & 2,5 & & 0 & 0 & \\
\hline \multicolumn{7}{|l|}{ Last education } \\
\hline Not completed in primary school & 6 & 15,0 & \multirow{5}{*}{$\begin{array}{c}7,02 \pm \\
3,39\end{array}$} & 3 & 7,5 & \multirow{5}{*}{$\begin{array}{c}8,70 \pm \\
2,37\end{array}$} \\
\hline Elementary school & 22 & 55,0 & & 18 & 45,0 & \\
\hline Junior high school & 7 & 17,5 & & 3 & 7,5 & \\
\hline Senior high school & 5 & 12,5 & & 14 & 35,0 & \\
\hline Post graduate & 0 & 0 & & 2 & 5,0 & \\
\hline \multirow{2}{*}{ Category } & \multicolumn{6}{|c|}{ Family } \\
\hline & \multirow{2}{*}{\multicolumn{2}{|c|}{$\mathrm{n}$}} & \multicolumn{2}{|l|}{$\%$} & \multicolumn{2}{|c|}{ mean \pm std } \\
\hline \multicolumn{5}{|l|}{ Family size (people) } & & \\
\hline Small family (0-4) & \multicolumn{2}{|c|}{15} & \multicolumn{2}{|l|}{37,5} & \multirow{2}{*}{\multicolumn{2}{|c|}{$5.00 \pm 1.695$}} \\
\hline Medium family(5-7) & \multirow{2}{*}{\multicolumn{2}{|c|}{$\begin{array}{r}22 \\
3\end{array}$}} & 55,0 & & & \\
\hline Large family $(>7)$ & & & \multicolumn{2}{|l|}{7,5} & & \\
\hline \multicolumn{7}{|l|}{ Length of marriage } \\
\hline Low $(<30)$ & \multicolumn{2}{|c|}{11} & \multicolumn{2}{|c|}{27,5} & \multirow{3}{*}{\multicolumn{2}{|c|}{$17.75 \pm 10.664$}} \\
\hline Medium (30-39) & \multirow{2}{*}{\multicolumn{2}{|c|}{$\begin{array}{l}18 \\
11\end{array}$}} & \multirow{2}{*}{\multicolumn{2}{|c|}{$\begin{array}{l}45,0 \\
27,5\end{array}$}} & & \\
\hline Height $(>39)$ & & & & & & \\
\hline
\end{tabular}

Last education. Husband and wife families of fishermen programs with a minimum education from elementary to tertiary education mostly owned by the husband $(55.5 \%)$ and wife $(45.0 \%)$. The lowest category of the education level of the 
respondent's husband at the level of not completing elementary school (15.0\%) was as many as six people. The average level of husband's education is 8.7 years, and the wife is 7.02 years or equivalent to graduating from elementary school.

Big family. Broad family groupings based on the number of family members classified into small families, medium families, and extended families (BKKBN, 2005). The highest number of members is in the moderate family category (55\%), with an average of five people.

Length of marriage. The results show that fishermen's family marriages are low, medium, and high. The categorization is the result of the standard deviation (emic) method of the long distribution of respondents' family marriages. The average length of family marriage ranges from 17.75 years. Families with a medium category of marriage have the highest proportion (45\%), ranging from 13 years to 26 years. The length of marriage varies from one to 44 years with an average marriage length of 17 years

Profession. The category of occupations in the study consists of fishermen, traders, not working, and others. The work of the respondent's husband in the sea season a whole as a fisherman. In the non-sea season, as many as (65.0\%) husbands work as fishermen, besides choosing to work on the land. Half of the respondents were housewives (50.0\%), while the rests were traders and others during the sea season. Half of the respondents have a job as a trader $(52.5 \%)$ in the season not going to sea, it is due to help the husband increase family income.

The family income per capita. The salary is categorized based on the South Bangka Regency Poverty Line (BPS, 2018), which is Rp. 483,823. Half the family income per capita in the sea season is above the poverty line $(52.5 \%)$. More than half of family income per capita in the non-fishing season falls below the poverty line $(87.5 \%)$. The average family income per capita in the sea season is IDR 620,673 , while in the non-sea season, it is IDR 389,422 .

Table 2 The distribution based on the economic characteristics of the respondent's family at sea and not at sea

\begin{tabular}{|c|c|c|c|c|c|c|c|c|}
\hline \multirow[t]{3}{*}{ Category } & \multicolumn{4}{|c|}{ Sea Season } & \multicolumn{4}{|c|}{ Non-Sea Season } \\
\hline & \multicolumn{2}{|c|}{ Husband } & \multicolumn{2}{|c|}{ Wife } & \multicolumn{2}{|c|}{ Husband } & \multicolumn{2}{|c|}{ Wife } \\
\hline & $\mathrm{n}$ & $\%$ & $\mathrm{n}$ & $\%$ & $\mathrm{n}$ & $\%$ & $\mathrm{n}$ & $\%$ \\
\hline \multicolumn{9}{|l|}{ Profession } \\
\hline Fishermen & 100 & 100.0 & 1 & 2.5 & 26 & 65.0 & 1 & 2.5 \\
\hline Trader & 0 & 0.0 & 14 & 35.0 & 9 & 22.5 & 21 & 52.5 \\
\hline The others & 0 & 0.0 & 5 & 12.5 & 5 & 12.5 & 10 & 32.5 \\
\hline Does not work & 0 & 0.0 & 20 & 50.0 & 0 & 0.0 & 8 & 12.5 \\
\hline \multicolumn{9}{|l|}{ Income } \\
\hline$<\mathrm{Rp} 483823$ & 0 & 0.0 & 28 & 70.0 & 3 & 7.5 & 9 & 22.5 \\
\hline$\geq \mathrm{Rp} 483823$ & 40 & 100.0 & 12 & 30.0 & 37 & 92.5 & 31 & 77.5 \\
\hline \multirow{3}{*}{ Category } & \multicolumn{8}{|c|}{ Family } \\
\hline & \multicolumn{4}{|c|}{ Sea Season } & \multicolumn{4}{|c|}{ Non-Sea Season } \\
\hline & \multicolumn{2}{|c|}{$\mathrm{n}$} & \multicolumn{2}{|c|}{$\%$} & \multicolumn{2}{|r|}{$\mathrm{n}$} & \multicolumn{2}{|c|}{$\%$} \\
\hline \multicolumn{9}{|l|}{ The family income per capita } \\
\hline$<$ Rp483 823 & \multirow{2}{*}{\multicolumn{2}{|c|}{$\begin{array}{l}19 \\
21\end{array}$}} & \multirow{2}{*}{\multicolumn{2}{|c|}{$\begin{array}{l}47.5 \\
52.5\end{array}$}} & \multirow{2}{*}{\multicolumn{2}{|c|}{$\begin{array}{l}28 \\
12\end{array}$}} & \multirow{2}{*}{\multicolumn{2}{|c|}{$\begin{array}{l}10.0 \\
30.0\end{array}$}} \\
\hline$\geq$ Rp483 823 & & & & & & & & \\
\hline
\end{tabular}

\section{Gender Roles}

Gender roles based on differences in roles, functions, and responsibilities of husband and wife as a result of agreements between husband and wife (Puspitawati, 2012). Gender roles are divided into three dimensions, namely domestic, public, and 
social, in which from the three domains, the cooperation between husband and wife in one family will be seen. The domestic dimension is an environment related to the collaboration of gender roles between husband and wife in activities inside the house and vice versa the public dimension, and social dimensions are the environment associated with the cooperation of gender roles between husband and wife in activities outside the home. The matter that distinguishes between the public and social community is that the public is related to the work of making money or goods, while the social community is voluntary.

Domestic. Table 3 shows that more than half of the gender roles of husband and wife domestic activities at sea $(80.0 \%)$ and non-sea periods $(75.0 \%)$ are in a low category. This shows that cooperation between husband and wife in the domestic dimension is still very low and is more dominant in one of the husband or wife. This is due to the domestic dimension of cooking and household chores, which are dominated by the wife, but the husband does not have much time to help the wife because she is busy working fishing in the sea. It is also explained that the wife completes the work of washing dishes, washing clothes, cleaning the house, shopping for groceries, cooking, managing family finances, and paying for electricity. At the same time, the husband plans to repair the house and repair the house when it is damaged. Husband and wife cooperation is balanced when caring for children, caring for children when sick, and planning for children's education. There is no family insurance, but there is fisherman insurance in some respondents.

Public. More than half of the gender roles of husband and wife in public activities at sea $(70.0 \%)$ and non-sea periods $(62.5 \%)$ are in a low category. The low category describes that there is little gender role cooperation taking place between husband and wife. This is due to the absence of optimal cooperation in doing work such as processing fish, selling fish catches, and working for a living more than eight hours per day. Husband and wife in gender cooperation are still more dominant husband or wife only. The husband works at sea while the wife at home and does not work in the sea season. However, in the sea season, there is an increase in gender role cooperation. The wife works when the season is not going to sea to help increase family income.

Social Community. Half of the gender roles of the social dimension of the sea season $(77.5 \%)$ and the season of not going to sea $(77.5 \%)$ are in the lower category. This shows the absence of cooperation between husband and wife in gender roles in the dimension of the social community is still low and is hardly done in the Tanjung Ketapang village community. This is due to only a small number of mutual cooperation in the neighborhood and RT / RW meetings. Gender role cooperation is more balanced by husband and wife in participating in religious activities and social organizations.

Based on the results of descriptive analysis of gender role variables, overall, it shows that the largest proportion $(92.5 \%)$ of gender role cooperation between husband and wife is carried out by one party in the sea season and $(80.0 \%)$ in the non-sea season. Gender role cooperation tends to be more dominant, with a proportion of 7.5 percent in the sea season and 20.0 percent in the non-sea season. No visible cooperation in gender roles is carried out in a balanced manner. This is alleged because the cooperation of roles in the three dimensions dominated by one of the parties, namely husband or wife, and is replaced by others, such as children or relatives who live at home, so there is less visible cooperation in gender roles between husband and wife. 
Paired sample T-test results indicate that there is a significant difference $(\mathrm{p}$ $<0.01$ ) in the gender dimension of the public with a p-value of $0,000 * * *$ and the total overall gender role p-value of $0.005 * *$ between season to sea and season not to sea. Differences in gender dimensions of the public dimension are found in the work activities of earning more than eight hours per day and increasing work hours.

Table 3 Respondents distribution based on gender roles

\begin{tabular}{|c|c|c|c|c|c|c|c|c|c|}
\hline \multirow[t]{2}{*}{ Gender roles } & \multicolumn{2}{|c|}{ Low $(<60)$} & \multicolumn{2}{|c|}{$\begin{array}{c}\text { Medium } \\
(60-79) \\
\end{array}$} & \multicolumn{2}{|c|}{$\begin{array}{l}\text { High } \\
(\geq 80)\end{array}$} & \multirow[t]{2}{*}{ Min-Max } & \multirow[t]{2}{*}{ Mean \pm SD } & \multirow{2}{*}{$\begin{array}{c}p- \\
\text { value }\end{array}$} \\
\hline & $\mathrm{n}$ & $\%$ & $\mathrm{n}$ & $\%$ & $\mathrm{n}$ & $\%$ & & & \\
\hline \multicolumn{10}{|l|}{ Domestic } \\
\hline Sea season & 32 & 80.0 & 8 & 20.0 & 0 & 0.0 & $22.22-77.78$ & $47.05 \pm 12.11$ & \multirow{2}{*}{0.232} \\
\hline Non-sea season & 30 & 75.0 & 10 & 25.0 & 0 & 0.0 & $24.44-73.33$ & $47.67 \pm 11.94$ & \\
\hline \multicolumn{10}{|l|}{ Public } \\
\hline Sea season & 28 & 70.0 & 4 & 10.0 & 8 & 20.0 & $13.33-100.00$ & $45.16 \pm 28.58$ & \multirow{2}{*}{$\begin{array}{c}0.000 \\
* * * \\
\end{array}$} \\
\hline Non-sea season & 25 & 62.5 & 6 & 15.0 & 9 & 22.5 & $13.33-100.00$ & $49.83 \pm 27.21$ & \\
\hline \multicolumn{10}{|l|}{ Social Community } \\
\hline Sea season & 31 & 77.5 & 7 & 17.5 & 2 & 5.0 & $8.33-100.00$ & $39.79 \pm 23.91$ & \multirow{2}{*}{0.118} \\
\hline Non-sea season & 31 & 77.5 & 4 & 10.0 & 5 & 12.5 & $8.33-100.00$ & $41.45 \pm 24.99$ & \\
\hline \multirow[t]{2}{*}{ Sea season } & 3 & 92.5 & 5 & 7.5 & 0 & 0.0 & $23.61-75.00$ & $45.45 \pm 11.07$ & \multirow{4}{*}{$\begin{array}{c}0.005 \\
* *\end{array}$} \\
\hline & 5 & & & & & & & 9 & \\
\hline \multirow[t]{2}{*}{ Non-sea season } & 3 & 80.0 & 8 & 20.0 & 0 & 0.0 & $25.00-75.00$ & $47.08 \pm 11.18$ & \\
\hline & 2 & & & & & & & & \\
\hline
\end{tabular}

Information: *significant at $\mathrm{p}<0.1 ; * *$ significant at $\mathrm{p}<0.05$; ***significant at $\mathrm{p}<0.01$

\section{Coping Strategies}

According to Lazarus and Folkman (1984), coping strategies are efforts to deal with problems through actions and perceptions to reduce or tolerate the effects caused by stress. Coping functions can be divided into two folds, namely, focus on the problem and focus on the emotions. The focus of problems related to regulation problems causes stress, while the focus on the emotions related to the regulation of emotions. Each coping strategy is classified into three, namely low, medium, and high, to determine the level of the type of coping strategy undertaken.

Focus Problem. Based on Table 4, it is mentioned that half of the coping strategies focus on the problems carried out by fishing families in the sea season $(50.0 \%)$ and the non-sea season $(57.5 \%)$ in the medium category. This also indicates that the family in this study does not maximize efforts to solve the problems it faces. In addition, half of coping focuses on the problem that always completed is knowing what needs to be done and working hard to succeed, learn from the past to solve current problems, make plans for each activity and run it, and fight hard to get the desired thing. Families often surrender to the conditions experienced and do not show anger to people who cause problems.

Focus Emotional. Coping strategies focus on the emotion of the sea season most $(57.5 \%)$ in the medium category and in the non-sea season are in the medium category $(62.5 \%)$. This shows that the family does not fully have a good emotional focus coping strategy. Emotional focus coping strategies are always done in the form of praying, not blaming others, turning into someone who is better, and hope that the difficulties faced quickly end. Families often apologize or do something to improve things, talk to others to find solutions, try not to think about problems too seriously, and try to look on the positive side. 
The total overall coping strategies of fishing families are in the moderate category of 60 per cent in the sea season with an average of 76.33 per cent and 67.5 percent in the non-sea season, with an average of 73.5 percent. This shows that the fishing families have completed coping strategies when facing a problem but have not maximized it. The family has tried to face the problem of the impact of seasonal changes that occur in fishing families. However, the business done by fishermen's family is not optimal in carrying out this.

Based on the Pair T-Test, it was found that there was a significant difference ( $p$ $<0.01)$ in the coping dimensions of emotions with a p-value of $0.000 * * *$ and total coping with a p-value of $0.000 * * *$. The difference in coping with the focus on emotions in this telling the difficulties experienced by others, asking relatives or friends who are trusted to get advice, keep feelings from being influenced by others, and see the positive side, trying not to think seriously about the problem, and not letting problems that occur affect the mind.

Table 4 Respondents distribution based on coping strategies

\begin{tabular}{|c|c|c|c|c|c|c|c|c|c|}
\hline \multirow{2}{*}{ Coping Strategies } & \multicolumn{2}{|c|}{$\begin{array}{c}\text { Low } \\
(<60) \\
\end{array}$} & \multicolumn{2}{|c|}{$\begin{array}{c}\text { Medium } \\
(60-79)\end{array}$} & \multicolumn{2}{|c|}{ Hight $(\geq 80)$} & \multirow{2}{*}{ Min-Max } & \multirow{2}{*}{$\begin{array}{c}\text { Mean } \pm \\
\text { SD }\end{array}$} & \multirow{2}{*}{$\begin{array}{l}p \text { - } \\
\text { value }\end{array}$} \\
\hline & $\mathrm{n}$ & $\%$ & $\mathrm{n}$ & $\%$ & $\mathrm{n}$ & $\%$ & & & \\
\hline \multicolumn{10}{|l|}{ Focus problem } \\
\hline Sea season & 3 & 7.5 & 20 & 50.0 & 17 & 42.5 & $55.56-100.00$ & $77.08 \pm 12.01$ & \multirow{2}{*}{0.662} \\
\hline Non-sea season & 4 & 10.0 & 21 & 57.5 & 15 & 37.5 & $44.44-100.00$ & $76.11 \pm 12.78$ & \\
\hline \multicolumn{10}{|l|}{ Focus emotion } \\
\hline Sea season & 0 & 0.0 & 23 & 57.5 & 17 & 42.5 & $64.00-98.00$ & $79.75 \pm 9.59$ & \multirow{2}{*}{$\begin{array}{c}0.000 * \\
* *\end{array}$} \\
\hline Non-sea season & 2 & 5.0 & 25 & 62.5 & 13 & 32.5 & $58.00-98.00$ & $76.95 \pm 9.51$ & \\
\hline \multicolumn{10}{|l|}{ Coping strategies } \\
\hline Sea season & 0 & 0.0 & 24 & 60.0 & 16 & 40.0 & $61.67-96.67$ & $76.33 \pm 9.31$ & \multirow{2}{*}{$\begin{array}{c}0.000 * \\
* *\end{array}$} \\
\hline Non-sea season & 2 & 5.0 & 27 & 67.5 & 11 & 22.5 & $56.67-96.67$ & $73.42 \pm 9.38$ & \\
\hline
\end{tabular}

\section{Family Happiness Index}

Aristotle in Williams et al. (2006), argues that happiness is a form of perfection, so many efforts are made to achieve it. This is in line with what was stated by Williams et al. (2006) that happiness is very important so that efforts to achieve happiness become the focus of attention and goals of humans all the time. The happiness index is a measure that describes the level of welfare because happiness is a reflection of the level of welfare that has been achieved by each individual (Kapteyn, Smith, \& Van Soest, 2010).

Information on Table 5 shows that there were more than half of the respondents with the most happiness $(75.0 \%)$ in the high category. Similarly, in the non-fishing season, more than half of the respondents had the highest level of happiness (70.0\%) in the high category. The average level of family happiness shows that high category $(86.0 \%)$ in the sea season and $(82.9 \%)$ in the non-sea season. It is suspected that respondents remain grateful and accept what they currently have so that the fishing families can be said to be happy with everything they have now. Respondents feel happy living with their families and have a good social relationship with the surrounding environment.

The family feels agree with the statement of family happiness. In the high category, the family feels harmonious, has a good social relationship with the 
community, often feels happy, has meaning from certain goals, and is grateful for family income. The family agrees with the statement that they feel happy with their work, feel happy with their skills, feel happy to live their lives, and are optimistic about their future. Families feel less agree or less satisfied with their homes and facilities and feel they have not found beauty in their lives.

Table 5 Sample distribution based on subjective well-being

\begin{tabular}{lccccccccc}
\hline \multirow{2}{*}{$\begin{array}{l}\text { Family } \\
\text { Happiness Index }\end{array}$} & \multicolumn{2}{c}{$\begin{array}{c}\text { Low } \\
(<60)\end{array}$} & \multicolumn{2}{c}{$\begin{array}{c}\text { Medium } \\
(60-79)\end{array}$} & \multicolumn{2}{c}{$\begin{array}{c}\text { High } \\
(\geq 80)\end{array}$} & Min-Max & Mean \pm SD & $p$-value \\
\cline { 2 - 7 } & $\mathrm{n}$ & $\%$ & $\mathrm{n}$ & $\%$ & $\mathrm{n}$ & $\%$ & & & \\
\hline Sea season & 0 & 0.0 & 10 & 25.0 & 30 & 75.0 & $62.22-100.00$ & $86.00 \pm 9.82$ & $\mathbf{0 . 0 0 0} * * *$ \\
Non-sea season & 0 & 0.0 & 12 & 30.0 & 28 & 70.0 & $62.22-97.78$ & $82.94 \pm 8.82$ & $\mathbf{0 . 0 0 0}$ \\
\hline
\end{tabular}

Information: *significant at $\mathrm{p}<0.1 ; * *$ significant at $\mathrm{p}<0.05 ; * * *$ significant at $\mathrm{p}<0.01$

\section{Correlation of Family Characteristics, Gender Roles, Coping Strategies, and Family Happiness Index}

In this study, the characteristics of the family describe the conditions of the fishermen's family structure. The dimensions of family characteristics that are interconnected can explain the picture of the condition of the family structure. The age of the wife shows a significantly positive relationship with the length of the marriage and family income. This shows that the older the wife, the longer the marriage and the number of family members increases. However, increasing the number of family members shows a significantly negative relationship with family income. This shows that the more the number of family members increases, the income per capita of the family decreases.

Table 6 Correlation coefficients of family characteristics, gender roles at sea, coping strategies of the seas season with the happiness index of families at sea

\begin{tabular}{|c|c|c|c|}
\hline Variable & $\begin{array}{c}\text { Gender roles of sea } \\
\text { season }\end{array}$ & $\begin{array}{c}\text { Coping strategies of sea } \\
\text { season }\end{array}$ & $\begin{array}{c}\text { Family happiness index of } \\
\text { sea season }\end{array}$ \\
\hline Wife's age & 0.172 & 0.089 & 0.102 \\
\hline Husband's age & 0.120 & 0.076 & 0.099 \\
\hline Wife's last education & -0.058 & 0.045 & 0.275 \\
\hline $\begin{array}{l}\text { Husband's last } \\
\text { education }\end{array}$ & -0.200 & 0.054 & 0.180 \\
\hline $\begin{array}{l}\text { Total of family } \\
\text { members }\end{array}$ & 0.248 & 0.051 & -0.079 \\
\hline Length of marr & 0.196 & 0.003 & -0.028 \\
\hline Husband income & 0.241 & 0.082 & 0.121 \\
\hline Gender roles & 1 & -0.165 & 0.124 \\
\hline Domestic & & 0.242 & -0.020 \\
\hline Public & & 0.029 & 0.121 \\
\hline Social community & & -0.041 & 0.203 \\
\hline Coping Strategies & & 1 & $0.399 * *$ \\
\hline Focus of problem & & & $0.353 * *$ \\
\hline Focus of emotion & & & $0.303 *$ \\
\hline Family happiness index & & & 1 \\
\hline
\end{tabular}

Information: *significant at $\mathrm{p}<0.1 ; * *$ significant at $\mathrm{p}<0.05 ; * * *$ significant at $\mathrm{p}<0.01$

Gender roles describe the division of tasks performed by a fishing family. The role of gender in the domestic dimension has a significant negative correlation with the length of the husband's education. This means that the higher the husband's education, 
the lower the gender dimension of the domestic dimension. The role of social gender is positively and significantly related to family income per capita. This shows that the higher the family income is obtained, the higher the social role dimensions of social dimensions are carried out. The correlation test results in Table 6 shows that the overall coping strategy is positively and significantly related to the happiness index. This shows that the higher the coping strategies carried out by the family, the happiness index of the fishermen's family will also be higher. The coping strategies focused on the problems were positively and significantly related to the happiness index. This also means that the more families solve problems well, the happier the family will be. The emotional focus coping strategies were positively and significantly related to the happiness index. This means that the more a family can manage emotional coping well, the happier the family will be.

The correlation results in Table 7 show that the role of domestic gender shows a significantly negative effect on coping strategies. This indicates that the higher the gender role of the domestic dimension, the higher the level of coping strategies in the season does not go to fishing families. The coping strategy of the season not to sea shows a significant positive correlation with the index of family happiness. This shows that the more families carry out coping strategies in the off-season season, the higher the happiness index of fishermen families. In the non-sea season, the coping strategies focus on emotions is positively and significantly related to the family index. This shows that the higher the family's emotional coping strategies adopted in the non-fishing season will increase family happiness. This is supported by Prenda and Lachman (2001), that if an individual who has a coping strategy will be able to control the event or overcome the problem at hand and can increase his life satisfaction.

Table 7 Correlation coefficients of family characteristics, gender roles of the season not going to sea, coping strategies of the season not going to sea with the happiness index of the season not going to sea

\begin{tabular}{lrrr}
\hline \multicolumn{1}{c}{ Variable } & $\begin{array}{c}\text { Gender roles of } \\
\text { non-sea season }\end{array}$ & $\begin{array}{c}\text { Coping strategies of } \\
\text { non-sea season }\end{array}$ & $\begin{array}{c}\text { Family happiness index of } \\
\text { non-sea season }\end{array}$ \\
\hline Wife's age & 0.085 & 0.162 & 0.132 \\
Husband's age & 0.092 & 0.176 & 0.129 \\
Wife's last education & 0.068 & 0.038 & 0.120 \\
Husband's last education & -0.185 & 0.084 & 0.122 \\
Total of family members & 0.164 & 0.140 & -0.034 \\
Long marriage time & 0.128 & 0.044 & 0.076 \\
Husband income & 0.170 & -0.123 & 0.096 \\
Gender roles & 1 & -0.161 & 0.084 \\
- Domestic & & $-0.286^{*}$ & -0.045 \\
- Public & & -0.077 & 0.074 \\
- Social community & & 0.026 & 0.205 \\
Coping Strategies & & 1 & $0.389^{* *}$ \\
- Focus of problem & & & 0.095 \\
- Focus of emotion & & & $0.346^{* *}$ \\
Family happiness index & & & 1 \\
\hline Information: *significant at $\mathrm{p}<0.1 ; * *$ significant at $\mathrm{p}<0.05 ; * * *$ significant at $\mathrm{p}<0.01$ &
\end{tabular}

The Influence of Family Characteristics, Gender Roles, Coping Strategies, and The Family Happiness Index

The effects of family characteristics, gender roles, and coping strategies on fishermen's family happiness index were analyzed using linear regression tests. Linear 
regression test in this study examines the influence of family characteristics, the average gender role of the sea and non-sea seasons, the average coping strategy of the sea, and non-sea seasons to the family index of the sea and non-sea seasons. Based on the results of regression tests on family characteristics, gender roles, and coping strategies on the happiness index presented in Table 8. The table shows that the Adjusted R Square value of the model in the sea season was 0.140 ( $\operatorname{sig} 0.019)$. These results mean that the variables studied, such as gender roles and coping strategies, influence as much as 14.0 percent on the happiness index. Meanwhile, the remaining 86.0 percent is influenced by other variables not examined. In the non-sea season, the Adjusted R Square value of the model is 0.115 ( $\mathrm{sig} 0.003$ ) that means in the variable used in this study is only 11.5 percent affecting the happiness index and the remaining 88.5 percent is influenced by other variables not examined in this research.

Table 8 Test results of the influence of family characteristics, social support, and coping strategies on the family happiness index in the sea and non-sea seasons

\begin{tabular}{|c|c|c|c|c|c|c|}
\hline \multirow{3}{*}{ Variable } & \multicolumn{6}{|c|}{ Family happiness index } \\
\hline & \multicolumn{3}{|c|}{ Sea season } & \multicolumn{3}{|c|}{ Non-sea season } \\
\hline & $\mathrm{B}$ & Beta & Sig & B & Beta & Sig \\
\hline Wife's age & 0.228 & 0.280 & 0.504 & 0.353 & 0.383 & 0.368 \\
\hline Husband's age & 0.156 & 0.169 & 0.685 & -0.087 & -0.105 & 0.804 \\
\hline Total of family members & -3.208 & -0.553 & $0.054 *$ & -2.740 & -1.873 & $0.070 *$ \\
\hline Long marriage time & 0.039 & 0.043 & 0.883 & 0.204 & 0.817 & 0.420 \\
\hline Husband's income & 0.000 & 0.007 & 0.963 & 0.00 & 0.734 & 0.468 \\
\hline Gender roles & 0.225 & 0.254 & 0.133 & 0.133 & 1.056 & 0.299 \\
\hline Coping Strategies & 0.455 & 0.431 & $0.008 * *$ & 0.423 & 2.815 & $0.008 * *$ \\
\hline $\mathrm{F}$ & & & 1.910 & & & 1.727 \\
\hline R-Square & & & 0.295 & & & 0.274 \\
\hline Adjusted R-Square & & & 0.140 & & & 0.115 \\
\hline Std. Error & & & 9.109 & & & 8.298 \\
\hline Sig & & & 0.019 & & & 0.003 \\
\hline
\end{tabular}

Information: *Signifikan to $\mathrm{p}<0,05 ; * *$ Signifikan to $\mathrm{p}<0,01$

The results showed that in the sea season, coping strategies had a significant and positive affect on the family happiness index $(B=0.455, \mathrm{p}=0.008)$. This can be interpreted that every increase of one coping strategy score will increase the family happiness index by 0.455 points. Families with higher coping strategies will have a higher index of happiness. The number of family members has a negative effect on the family happiness index $(B=-3.208, p=0.054)$. This means that each increase in one score, the number of family members will reduce the happiness index by 3,208 points. In the non-sea season, the coping strategy has a significant and positive affect on the happiness index $(\mathrm{B}=0.423, \mathrm{p}=0.008)$. This can be interpreted that everyone coping strategy score will increase the family happiness index by 0.423 points. Families with higher coping strategies will have a higher index of happiness. However, the number of members has significantly and negatively affect the family happiness index $(B=-2,740$, $\mathrm{p}=0.070$ ). This means that each increase in one score, the number of family members will reduce the family happiness index by 2,740 points. Families with a higher number of members will have a lower happiness index. Therefore, the happiness Index can be formed by coping strategies possessed by fishing families in the sea and non-sea seasons. The happiness index will decrease if the number of family members of fishermen increases in the sea season and the non-sea season. 
The gender role of the regression test results did not significantly influence the happiness index. This means that the division of roles carried out in the family does not produce happiness in the fishing families. While coping strategy variables affect the happiness of fishermen families. Coping strategies have dimensions of focus on problems and focus on emotions. Coping strategies focus on the problem with a significant positive effect on the happiness index. This also means that the more families solve problems well, the happier the family will be. Emotional focus coping strategies have a significant positive effect on the happiness index. This means that the more a family can manage emotional coping well, the happier the family will be.

\section{Discussion}

This research employs a structural-functional theory approach through gender roles, coping strategies, and the family happiness index. Newman and Grauerholz (2002), revealed that the approach of this theory is used to analyze the role of each family in order to function properly to maintain family integrity. One important aspect from the perspective of the functional, structural theory is that every healthy family has a clear division of roles or functions of the family and functions it is patterned in a harmonious hierarchical structure and commitment to the implementation of roles (Puspitawati 2012). Family characteristics in this study found the age of husband and wife, husband and wife education level, number of family members, length of the marriage, employment, and income. The results showed that the wife's age and husband's age were mostly in the early adult category, which was 57.5 percent for wives with an average age of 38.82 years and 52.5 percent for husbands with an average age of 41.85 years. There are 45 percent of wives and 55 percent of husbands only attending primary school (6 years). The highest number of members in the moderate family category, with members of five to seven people, is 55 percent with an average family size of five people. The number of family members is at least two people and a maximum of nine people. Families with medium category marriages have the highest proportion of 45 percent ranging from 13 years to 26 years. The length marriage of fisherman families in this study ranged from one to 44 years, with an average length of the marriage of 17 years.

The work of the husband of the respondent in the fishing season works as a fulltime fisherman because it is a requirement to become a respondent. In the non-fishing season, 65 percent of the husband's work continues to work as a fisherman. Jobs other than fishermen include drivers motorcycle, becoming laborers in tin mining companies, and working in gardens. The most dominant fisherman's wife in the sea season is a housewife. The wife's work found besides trading is gardening and trading. The family income per capita per month in the sea season is 72.5 percent, and family income per capita per month in the sea season is 87.5 percent. The average family income per capita per month during the fishing season is IDR 517 200.00, while the average family income per capita per month in the non-fishing season is IDR 334260.00.

According to the research by Puspitasari, Puspitawati, and Herawati (2013), gender is the different roles, functions, requirements, positions, responsibilities, and behavioral rights of both women and men that are created, formed, and then socialized by the norms, customs, and beliefs of the local community. The results showed that there were differences in gender roles between the sea and non-sea seasons. The role of the fisherman's wife is even greater when the season is not going to sea. Women have a 
greater advantage in domestic work than men, so women will allocate time for domestic work while men make a living (Becker, 1974). According to Andriati (2016), that de facto the role of the fishermen's wife is very large and is responsible for meeting their household needs. More husbands at home when the season is not going to sea due to more extreme weather, so some wives of fishing families work outside the home to help family income and keep doing housework. The gender roles of the domestic, public, and social sectors are in a low category. Fisherman families have to do balanced cooperation in the sea and non-sea seasons so that a good gender role occurs.

The coping theory is identified by using two processes, namely focusing on problem solving and cognitive assessment as an intermediary of pressure between a person and his environment and solving problems in the long run (Folkman, Lazarus, Dunkel-Schetter, DeLongis, \& Gruen, 1986). The problem focus coping strategy and the emotional focus coping strategy applied by the fishermen's family in the sea and non-sea seasons are in the medium category. The results showed that there was a difference between emotional focus coping strategies and total coping strategies in the sea and non-sea seasons. That is because fishing families try to balance and try to be able to control the emotions that arise due to seasonal changes that occur. When a person experiences stress in his life, someone uses a way to rebalance his life by reducing or changing the source of the problem and also reducing the stress experienced in his life by changing the emotional response to the problem at hand (Richter, Lauritz, Preez, Cassimjee, \& Ghazinour, 2013). Happiness levels increase if emotions affect the frequency and intensity of positive effects such as joy and excitement, and decrease if emotions affect the frequency and intensity of negative effects such as anger and fear (Olsson, McGee, Raja, \& Williams, 2012).

Seligman, Steen, Park, and Peterson (2005), explained that happiness is a concept that refers to positive emotions felt by someone and positive activities that have no feeling components at all. According to Easterline (1974), measuring happiness should not only consider welfare goals not to be like health and socio-economic status but to subjective welfare measures such as satisfaction and quality of life. The results showed that fisherman families show a high happiness index. It can be seen that the respondent's family is still grateful and accepting of everything that they have owned despite having economic problems that are quite difficult to deal with. There is a significant difference in the index of happiness in the sea and not fishing. This is in line with the research of Ghani et al. (2017) that the challenges faced by fishing families will affect the quality of life of the fishing families.

The correlation test results showed that the coping strategy was significantly and positively related to the happiness index. This means that the more coping strategies are, the higher the happiness index of a fishing family in the sea and non-sea seasons. This is in line with Carr (2004), that coping strategies are very closely related to happiness. A study conducted by Azizi (2012) stated that there was a significant positive correlation between coping styles and happiness. The gender role of the correlation test results is not significantly related to the happiness index. This means that the division of roles carried out in the family does not make happiness in the fishing families. Gender roles that are carried out in the domestic dimension, such as cleaning the house or preparing food and division of roles in the public dimension such as adding work, do not necessarily provide happiness for the fishing families. In line with the research of Puspitasari, Puspitawati, and Herawati (2013), that there is no significant correlation between gender roles, both in domestic and public activities and the subjective well- 
being of families.

Based on the results of the regression test, coping strategies have a significant positive effect on the happiness index. This can interpret that the higher the coping strategies that occur between husband and wife, the increasing the index of happiness of a family. This is in line with the opinion of Prenda and Lachman (2001), showing that individuals who have coping strategies will be able to control the events or overcome the problems encountered to increase satisfaction. This condition caused by the more frequent coping strategies undertaken. The husband and wife increasingly respect each other and share the problems faced and share the emotions that are felt so that the family happiness index is higher. The number of family members has a significant negative effect on the happiness index. This can be interpreted that the higher the number of family members, the decrease in a family's happiness index. According to the official BPS statistics happiness index (2014), if the number of family members increases to six or more people, then the family happiness index tends to decrease. The gender role played by the fishing families does not affect the family happiness index. In line with Lianawati's research (2008), that there is no psychological well-being found in the families of married couples with different attitudes of gender roles.

Based on the results of the study that the family happiness index is higher in the sea season than in the non-sea season. Fishermen feel happier in the sea season than when the not-sea conditions are not going to sea. Coping strategies used are higher in the sea season than in the non-sea season. However, coping strategies that are done well in the non-sea season can increase family happiness. That means families must maximize coping strategies in the sea season. The gender role played by fishing families is higher in the sea season than in the non-sea season.

In this study, several other factors affect the happiness index of fishermen families, such as social support within the family. Previous research said that an adequate level of social support in the family is thus important for individual happiness (Adams, King, \& King 1996; North et al., 2008). Happiness is not only measured by material or physical things but about the comfort of the heart. Maslow, in Wenas, Opodo, and Pali (2015), revealed that if a human's basic needs are fulfilled, then a sense of security will emerge. That feeling of security is called happiness. Other factors that influence happiness in a fisherman's family are the health of family members, belief in God Almighty, environmental conditions, availability of free time, and togetherness of family members. Seligman, Steen, Park, and Peterson (2005), states that religious beliefs can increase faith, to prevent despair and can increase happiness.

This study has limitations, including data obtained from one source, namely, a wife. Interviews should be conducted with both parties, namely a couple between husband and wife, so that the results obtained become more concrete. The results of this study cannot be generalized as a whole because it is located in Toboali District, South Bangka, Bangka Belitung Province.

\section{Conclusion and Recommendation}

\section{Conclusion}

The results showed that the majority of respondents aged 18 to 40 years were in the early adult category. The age of the husband shows that at most, 18 to 40 years are in the early adult category. The highest education level of respondents who graduated from elementary school and husbands also graduated from elementary school. The 
respondent's husband works as a fisherman in the sea and non-sea seasons. In the nonsea season, it shows that the respondent's husband is looking for other side jobs on the mainland because the income for fishing is reduced. This makes the wife have to work outside the home to increase family income. Half the fishing families have an income above the poverty line of the South Bangka in the sea season, while in the non-sea season, the family income is below the poverty line. The income of the husband in the sea season all respondents have income above the poverty line. Based on the results of the study, more than half of the respondent families are of the moderate family type with an average family size of five people. The results showed that the variables of gender roles, coping strategies, and happiness index of fishermen families are in the medium category. This shows that cooperation in the division of gender roles in the family as well as coping strategies that are established between husband and wife to realize the happiness index of fishermen families are quite well established.

Correlation test results show that there is a correlation between coping strategies with the happiness index of fishermen's families in the sea and non-sea seasons. Dimensions of coping strategies focus on problems, and coping strategies of emotional focus are interconnected with each other in the sea and non-sea seasons. Regression test results show that the number of family members shows a significantly and negatively affect the happiness index of fishermen's families in the sea and non-sea seasons. The results of the regression test showed that the coping strategy showed a significantly and positively affect the happiness index of fishermen's families in the sea and non-sea seasons.

\section{Recommendation}

Based on the results of the study, families should apply the principle of gender cooperation, in the division of roles to achieve a prosperous family. The study recommends to husband and wife to work together in carrying out gender roles in the domestic, public, and social domains, both in the sea and non-sea seasons. This situation will create no husband/wife party is more burdened in carrying out his role. The recommendation for further research is to analyze more deeply the effect of the happiness index. In addition, it is recommended to the future study to examine the happiness index variable, but with other independent variables that are different to see other factors that can affect the happiness index of fishermen's families. For the government, it is suggested to conduct education on saving and entrepreneurship education for the fishing community so that they will be able to change in behavior and family income that is not spent directly.

\section{Reference}

Abdullahi, A., Hassan, A., Kadarman, N., Saleh, A., Baraya, Y. U. S. A., \& Lua, P. L. (2016). Food safety knowledge, attitude, and practice toward compliance with abattoir laws among the abattoir workers in Malaysia. International Journal of General Medicine, 9, 79-87. https://doi.org/10.2147/ijgm.s98436

Adams, G. A., King, L. A., \& King, D. W. (1996). Relationships of job and family involvement, family social support, and work-family conflict with job and life satisfaction. Journal of Applied Psychology, 81(4), 411-420. https://doi.org/10.1037/0021-9010.81.4.411 
Andriati, R. (2016). Changes in fishing work culture. Journal of Bio Culture, 5(1), 61-74.

Astuti, Y. (2015). Subjective well-being in adolescents from broken home families [thesis]. Surakarta: Muhammadiyah University.

Azizi, M. (2012). Relationship between happiness and stress coping strategies among Zabol university students in academic year of 2010-11. Advances in Natural and Applied Sciences, 6(2), 163-167.

Becker, G. S. (1974). A Theory of Social Interactions. Journal of Political Economy, 82(6), 1063-1093. https://doi.org/10.1086/260265

[BKKBN] National Family Planning Coordinating Board. (2005). Family Planning and Reproductive Health. Jakarta: BKKBN.

[BPS] Statistics Indonesia. (2014). Guidelines for Implementing Happiness Measurement Study (SPTK) 2014. Jakarta (ID): Deputy for Statistics.

[BPS] Statistics Indonesia. (2017). Guidelines for Conducting a Study of Happiness Measurement (SPTK) 2017. Jakarta (ID): Deputy of Statistics.

[BPS] South Bangka in Figures 2018 (ID)

Carr, A. (2004). Positive psychology: New worlds for old. Journal of Irish Psychologist, 30 (11), 278-279. https://doi.org/10.4324/9780203506035

Davies, S. (1993). Are coping strategies a cop out?. IDS bulletin, 24(4), 60-72. https://doi.org/10.1111/j.1759-5436.1993.mp24004007.x

Diener, E., Lucas, R.E., \& Oishi, S. (2005). Subjective Well Being: The Science of Happiness and Life Satisfaction. Handbook of Positive Psychology. New York (US): Oxford University Press.

Easterlin, R. (1974). "Does economic growth improve the human lot? Some empirical evidence ". In Nations and Household economic growth: Essays in Honor of Moses Ambramovitz. Edited by Paul A. David and Melvin W. New York (USA): Academic Press.

Folkman, S., Lazarus, R. S., Dunkel-Schetter, C., DeLongis, A., \& Gruen, R. J. (1986). Dynamics of a stressful encounter: cognitive appraisal, coping, and encounter outcomes. Journal of Personality and Social Psychology, 50(5), 992. https://doi.org/10.1037/0022-3514.50.5.992

Franklin, \& Samuel, S. (2010). The Psychology of Happiness. New York (USA): Cambridge University Press.

Ghani, N. A., Raub, M. A., Adam, F., Abdullah, B., Afgani, Y., \& Eusoff, D. A. H. (2017). Quality of Life (QoL) of fishermen in the West Coast States of Peninsular Malaysia. International Journal of Academic Research in Business and Social Sciences, 7(4), 2222-6990. https://doi.org/10.6007/ijarbss/v7$\mathrm{i} 4 / 2808$

Hills, P., \& Argyle, M. (2002). The Oxford Happiness Questionnaire: a compact scale for the measurement of psychological well-being. Personality and Individual Differences, 33(7), 1073-1082. https://doi.org/10.1016/s01918869(01)00213-6

Hurlock, E. (1980). Developmental Psychology. New York (USA).

Imron, M. (2003). Poverty in fishing communities. Journal of Society and Culture, 5(1), 63-82.

Irwan, A., Nugroho, F., \& Zulkarnain, Z. (2017). The Fishing Activity on North Seasons in the Village of Batu Limau Ungar Subdistrict Karimun Regency 
Riau Island Province of Indonesia (Doctoral dissertation, Riau University).

Kahneman, D., Diener, E., \& Schwarz, N. (1999). Well-being: The foundations of Hedonic Psychology. New York (USA): Russell Sage Foundation.

Kapteyn, A., Smith, J. P., \& Van Soest, A. (2010). Life satisfaction. International Differences In Well-Being, 70-104. https://doi.org/10.1093/acprof:oso/9780199732739.003.0004

[KBBI] Large Indonesian Dictionary. [On line]. Available at: http://kbbi.web.id/bahagia, [Accessed February 2, 2020].

Khomsan, A., Anwar, F., \& Mudjajanto, E. S. (2009). Nutritional knowledge, attitude and practice of Posyandu participants. JURNAL GIZI DAN PANGAN, 4(1), 33-41.

Kusumo, R.A.B., Sunarti, E., \& Pranadji, D.K. (2008). Analysis of gender roles and their relationship to the welfare of families of rice farmers and horticulture in urban suburbs. Nutrition \& Family Media, 32(2), 52-64.

Kusumo, R.A.B., Charina, A., \& Mukti, G.W. (2013). Gender analysis in the lives of fisherman families in Pangandaran District, Ciamis Regency. Journal of Social Economic of Agriculture, 2(1), 42-53.

Krzaklewska. (2014). Working Paper No. 1.2 "Gender Equality and Quality of Life State of Art Report". Measurement of Gender Equality - Analyzing Dimensions, Embracing Areas, Considering Contexts.

Latifah, E. W., Hartoyo, \& Gurahdja, S. (2010). Perceptions, attitudes, and coping strategies of poor families related to the kerosene to LPJ conversion program in Bogor City. Journal of Family and Consumer Sciences, 3(2), 122-132.

Lazarus, R. S., \& Folkman, S. (1984). Stress, appraisal, and coping. Springer publishing company.

Lazarus, R. S. (1993). Coping theory and research. Journal of Psychosomatic Medicine, 55, 234-247. https://doi.org/10.1097/00006842-199305000-00002

Lianawati, E. (2008). Wife's Psychological Welfare Judging from the Attitude of Gender Roles in Muslim Couples. Journal of Psychology, 2(1), 29-41.

Mashuri. (1999). Empowerment of Underdeveloped Fishermen in Overcoming the Economic Crisis: Study An Approach. Jakarta(ID): Center for Economic Development and Development, LIPI.

Moser, C. O. N. (1993). Gender Planning and Development: Theory, Practice, and Training. New York (USA): Routledge. https://doi.org/10.4324/9780203411940

Muflikhati, I. (2010). Analysis of the development of models for improving the quality of human resources and welfare [dissertation]. Bogor: IPB University.

Newman, D.M., \& Grauerholz. (2002). Sosiologi of Families. Thousand Oaks (California) : Pine Forge Press.

Olsson, C. A., McGee, R., Raja, S. N., \& Williams, S. M. (2012). A 32-Year longitudinal study of child and adolescent pathways to well-being in adulthood. Journal of Happiness Study, 14(3),10691083. https://doi.org/10.1007/s10902-012-9369-8

Prenda, K. M., \& Lachman, M. E. (2001). Planning for the future life: A life management strategy for increasing control and life satisfaction in adulthood. Journal Psychology and Aging, 16(2), 206-216. https://doi.org/10.1037/08827974.16.2.206 
Puspitasari, N., Puspitawati, H., \& Herawati, T. (2013). The role of gender, women's economic contribution, and family welfare of horticultural farmers. Journal of Family and Consumer Sciences, 6(1), 10-19. https://doi.org/10.24156/jikk.2013.6.1.10

Puspitawati, H. (2013). Gender Concepts, Theories and Analysis. Bogor(ID): IPB Press.

Richter, J., Lauritz, L. E., Preez, E., Cassimjee, N., \& Ghazinour M. (2013). Relationships between personality and coping with stress: An investigation in Swedish police trainees. Journal of Psychology, 4(2),88-95. https://doi.org/10.4236/psych.2013.42012

Saefudin. (2003). Marine Meteorology. Jakarta: Bina Citra Samudra Foundation.

Seligman, M. E. P., Steen, T. A., Park, N., \& Peterson, C. (2005). Positive psychology progress: Empirical validation of interventions. American Psychologist Journal, (60), 410-421. https://doi.org/10.1037/0003066x.60.5.410

Suandi. (2007). Social capital and family welfare in rural areas of Jambi Province [dissertion]. Bogor: Bogor Agricultural University.

Sunarti, E., Ifada, Q., Desmarita, I., \& Hasanah, S. (2005). Family Resilience, stress management, and fulfillment of the economic function and socialization functions of the victims of the Aceh riots. Journal of Nutrition and Family Media, 29(1), 41-49.

Wahyono, A., Imron, M., \& Nadzir, I. (2014). The resilience of fisherman communities in responding climate change: a case study In Grajagan Pantai Village, Banyuwangi, East Java. Jurnal Masyarakat dan Budaya, 16(2), 259274.

Wenas, G. E., Opod, H., Pali, C. (2015). Relationship of happiness and family's socio-economic status in Artembaga II Urban Village, Bitung City. EBiomedical Journal, $\quad 3 \quad$ (1), 532-538. https://doi.org/10.35790/ebm.3.1.2015.7821

Williams, G. C, Lynch, M. F, McGregor, H. A, Ryan, R. M, Sharp, D, \& Deci, E. L. (2006). Validation of the important other climate questionnaire: assessing autonomy support for health-related change. Journal of Families, Systems, and Health, 24(2), 179-194. https://doi.org/10.1037/1091-7527.24.2.179 